\title{
CYP2C19 polymorphism frequency in Russian patients in Central Russia and Siberia with acute coronary syndrome
}

This article was published in the following Dove Press journal:

Pharmacogenomics and Personalized Medicine

12 April 2017

Number of times this article has been viewed

\section{Karin B Mirzaev' \\ Elena M Zelenskaya ${ }^{2}$ \\ Olga L Barbarash ${ }^{3}$ \\ Vladimir I Ganyukov ${ }^{3}$ \\ Konstantin A Apartsin ${ }^{4,5}$ \\ Natalya O Saraeva ${ }^{4}$ \\ Konstantin Y Nikolaev ${ }^{6,7}$ \\ Kristina A Ryzhikova' \\ Galina I Lifshits $2,5,7$ \\ Dmitry A Sychev'}

'Russian Medical Academy of Continuous Professional Education, Ministry of Health of the Russian Federation, Moscow, ${ }^{2}$ Federal StateFinanced Research Institution "Institute of Chemical Biology and Fundamental Medicine", Siberian Branch of the Russian Academy of Sciences, Novosibirsk, ${ }^{3}$ Federal State-Financed Research Institution "Research Institute for Complex Issues of Cardiovascular Diseases", Siberian Branch of the Russian Academy of Sciences, Kemerovo, ${ }^{4}$ State-Financed Health Institution "Irkutsk Regional Badge of Honour Clinical Hospital", ${ }^{5}$ Federal State-Financed Research Institution "Irkutsk Research Center", Siberian Branch of the Russian Academy of Sciences, Irkutsk City, ${ }^{6}$ Federal State-Financed Research Institution "Research Institute of Internal and Preventive Medicine", ${ }^{7}$ Federal State Autonomous Institution of Higher Education "Novosibirsk National Research State University", Novosibirsk, Russia

Correspondence: Karin B Mirzaev Russian Medical Academy of Postgraduate Education, Ministry of Health of the Russian Federation, Barrikadnaya Street 2/I, Moscow 123995, Russia

Tel +79852720253

Email karin05doc@yandex.ru
Purpose: The aim of this study is to investigate the frequency of $C Y P 2 C 19 * 2, * 3$ allelic variants, associated with poor response to clopidogrel, and $C Y P 2 C 19^{*} 17$, associated with excessive response to clopidogrel, in patients with acute coronary syndrome (ACS) from Siberia and Moscow regions of Russia.

Patients and methods: The study included 512 ACS patients who were subsequently treated with coronary arterial stenting. The subjects assigned were from the cities of Central (Novosibirsk, Kemerovo), Eastern (Irkutsk), Northern (Surgut) Siberia regions and from Moscow region. The mean age of patients enrolled was $63.9 \pm 10.9$ years. Among the assigned subjects, the proportion of men accounted for $80 \%$ and women $20 \%$.

Results: According to the results obtained in the present study, from $16 \%$ up to $27.5 \%$ of patients in different regions of Russia have at least one CYP2C19 "poor metabolizer" (PM) allele variant affecting clopidogrel metabolism and, therefore, suppressing its antiplatelet activity. CYP 2 C $19 * 17$ allele variant was identified with the frequency of $15.4 \%$ up to $33.3 \%$. The study revealed the presence of statistically significant differences in $C Y P 2 C 19 * 3$ allele frequency between the Russian ethnic group patients from Eastern and Central Siberia $(p=0.001$; odds ratio $=1.05$ [95\% confidence interval 1.01-1.09]).

Conclusion: The study revealed statistically significant differences between the allele frequencies in Eastern and Central Siberia, which can probably be caused by a considerable number of Buryats inhabiting Eastern Siberia.

Keywords: P2Y12 receptor inhibitors, clopidogrel resistance, dual antiplatelet therapy

\section{Introduction}

Over the recent decade, coronary heart disease (CHD) has been a leading cause of mortality as reported by the World Health Organization in 2014. ${ }^{1}$ An estimated 7.4 million people died from CHD in 2012, accounting for $13.2 \%$ of the total number of deaths. A major concern of contemporary cardiology practice is considered to be prevention of stent thrombosis in patients with acute coronary syndrome (ACS). The stented patients are treated with antiplatelet therapy aimed at preventing stent occlusion. ${ }^{2}$ Plavix (clopidogrel), as a part of dual antiplatelet therapy, is the most commonly used agent in Russian practice. Obviously, it is due to its affordability and generic versions availability, which reduces the treatment costs. However, according to European Society of Cardiology Guidelines, clopidogrel can no longer be recognized as a first-line therapy drug because of diminished response demonstrated by a number of patients. This resistance has been associated with genetic polymorphisms of $C Y P 2 C 19$ affecting clopidogrel metabolism. ${ }^{3}$ Therefore, it is crucial for antiplatelet therapy implementation to determine 
the frequencies of important alleles of cytochrome CYP2C19 gene. These polymorphism frequencies have not been much studied in Russian population, still less in Siberian region.

The allele of CYP2C19 gene is classified into the socalled "poor" and "rapid" alleles affecting clopidogrel metabolism. Allele variants that affect $C Y P 2 C 19$ isoenzyme metabolic activity the most are $C Y P 2 C 19 * 2$ and $C Y P 2 C 19 * 3$ (Gly681Ala and Gly636Ala, respectively). They were observed to be associated with reduced cytochrome activity, ${ }^{4,5}$ while CYP2C19*17 (Cys806Thr) polymorphism is known to cause augmented substrate metabolism. ${ }^{6}$

It has been observed that carriers of at least one "poor metabolizer" (PM) allele of CYP2C19 demonstrate higher residual platelet reactivity when on clopidogrel, which indicates poor clinical outcome in stented patients and higher risk of postoperative stent thrombosis. ${ }^{7,8}$ Prevalence of carriers of two polymorphic CYP2C19 alleles, affecting metabolism, is $15 \%$ and $35 \%$ in Caucasians and South and Central Asia population, respectively, ${ }^{9}$ which is considered to be significant for Siberian heterogenetic population. ${ }^{10}$

This article is the first to present data on frequency of CYP2C19*2, *3, and *17 allele variants in patients with ACS from Siberian and Moscow regions of Russia.

\section{Patients and methods}

The study included 512 ACS patients from Russian ethnic groups who were subsequently treated with coronary arterial stenting. The subjects assigned were from the cities of Central (Novosibirsk, Kemerovo), Eastern (Irkutsk), Northern (Surgut) Siberia regions and from Moscow region.

Written informed consent was obtained from all participants before entering the study. The research has been approved by the local ethics committees (of State-Financed Health Institution "Irkutsk Regional Badge of Honour Clinical Hospital," Federal State-Financed Institution "Research Institute for Complex Issues of Cardiovascular Diseases" of Siberian Branch of the Russian Academy of Sciences, State-Financed Health Institution of Novosibirsk region "City Clinical Hospital № 1," State-Financed Institution of KhantyMansi Autonomous Okrug-Yugra District Cardiologic Dispensary "Center of Diagnostics and Cardiovascular Surgery," Institute of Chemical Biology and Fundamental Medicine of Siberian Branch of the Russian Academy of Sciences, Federal State-Financed Institution of Further Professional Education "Russian Medical Academy of Postgraduate Education" of Ministry of Health of the Russian Federation, Pirogov City Clinical Hospital № 1).

The mean age of patients enrolled was $63.9 \pm 10.9$ years. Among the assigned subjects, the proportion of men accounted for $80 \%$ and women $20 \%$. All the patients were administered dual antiplatelet therapy - clopidogrel (300 mg - loading dose, $75 \mathrm{mg}$ - maintenance dose) as a part of complex medication therapy. The subjects were also given pharmacogenetic testing provided by Pharmacogenomics Laboratory of the Institute of Chemical Biology and Fundamental Medicine, SB RAS and the Research Center of Federal State-financed Institution of Further Professional Education "Russian Medical Academy of Postgraduate Education" of Ministry of Health of the Russian Federation.

\section{CYP2C19 genotyping}

The study was conducted on the blood samples $(4 \mathrm{~mL})$ collected from the veins of the bend of the elbow with ethylene diamine tetraacetate vacutainer tubes VACUETTE ${ }^{\circledR}$ (Greiner Bio-One, Austria). This procedure was performed on the 3rd-5th days as of hospitalization date. DNA extraction from leukocytes was carried out using laboratory reagents kit "DNA - EKSTRAN-1" (ZAO Syntol, Russia). Isolated DNA was then being stored at $-80^{\circ} \mathrm{C}$. Genotyping of $C Y P 2 C 19 * 2$, $C Y P 2 C 19 * 3$, and $C Y P 2 C 19 * 17$ allele variants was performed with "Pharmacogenetics Clopidogrel" (DNA-Technology Ltd, Russia). Genotyping for CYP2C19 was performed with the use of an oligonucleotide ligation assay after initial specific amplification by means of a polymerase chain reaction (PCR) involving three primers for the major variant alleles CYP2C19*2 (c.G681A; rs4244285), CYP2C19*3 (c.G636A;rs4986893), and CYP2C19*17 (c.C806T; rs 12248560). Primers: $5^{\prime}$-GATATGCAATAATTTTCCCACTATCATTG-3' and 5'-GGTGTTCTTTTACTTTCTCCAAAATATCAC-3' were used to amplify sequence of the CYP2C19*2 681G.A (rs4244285) in exon 5; for CYP2C19*3 (c.636G>; rs4986893), we used 5'-CACCCTGTGATCCCACTTTC-3' and 5'-ACTTCAGGGCTTGGTCAATA-3'; for CYP2C19*17 (c.C806T; rs12248560), we used $5^{\prime}$-AAATTTGTGTCTTCTGTTCTCAAA- $3^{\prime}$ and 5'-AATCCCAGTTCTGCCAGCTA- $3^{\prime}$. The sequence of the $\mathrm{G}$ allele-specific probe was $5^{\prime}$-FAM-TTATTTCCCGGGAACC-3', and the sequence of the A allele-specific probe was 5'-VIC-ATTATTTCCCAGGAACC-3'.

Base numbering and allele definitions follow the nomenclature of the Human Cytochrome P450 (CYP) Allele Nomenclature Committee (www.cypalleles.ki.se). The genotypes were determined with a TaqMan ${ }^{\circledR}$ Single Nucleotide Polymorphism Genotyping Assay kit and a TaqMan Universal PCR Master Mix (Applied Biosystems, Foster City, CA, USA), according to the manufacturer's instructions, using an ABI PRISM ${ }^{\circledR}$ Sequence Detector 7000 (Applied Biosystems). All the PCR reactions were carried 
out in a $10-\mu \mathrm{L}$ reaction volume containing genomic DNA $10 \mathrm{ng}$, oligonucleotide primers $0.5 \mathrm{pM}, 1 \mu \mathrm{L} 10$ PCR buffer, deoxynucleotides (dNTPs) $250 \mu \mathrm{M}$, magnesium chloride $3 \mathrm{mM}$, and DNA polymerase $0.25 \mathrm{U}$. The cycling program involved preliminary denaturation at $95^{\circ} \mathrm{C}$ for $10 \mathrm{~min}$, followed by 30 cycles of denaturation at $95^{\circ} \mathrm{C}$ for $30 \mathrm{~s}$, annealing at $60^{\circ} \mathrm{C}$ for $60 \mathrm{~s}$, and elongation at $72^{\circ} \mathrm{C}$ for $60 \mathrm{~s}$, followed by a final elongation step at $72^{\circ} \mathrm{C}$ for $7 \mathrm{~min}$ (18). CYP2C19 $* 1 / * 1$ carriers are designated as "extensive metabolizers," CYP2C19*2 or CYP2C19*3 carriers $(* 2 / * 2, * 2 / * 3, * 3 / * 3)$ as "PMs," and CYP2C19 (*1/*2, *1/*3, *2/*17,*3/*17) carriers as "intermediate metabolizers" (IMs). CYP2C19*17 $(* 1 / * 17, * 17 / * 17)$ carriers are designated as "ultra-rapid metabolizers" (UMs).

\section{Statistical analysis}

Statistical processing of the results was performed using the GraphPad InStat (GraphPad). Mean values are presented as $\mathrm{M} \pm \mathrm{SD}$, where $\mathrm{M}$ is mean and $\mathrm{SD}$ is standard deviation. To determine distinctions in categorical variables between groups, the Pearson's chi-squared $\left(\chi^{2}\right)$ test was used. To check on compliance with the Hardy-Weinberg equilibrium, the Fisher's exact test was applied. Differences with $p<0.05$ were regarded as significant.

\section{Results}

The present study was designed to investigate the frequency of CYP2C19 "PM" allele variants (CYP2C19*2, CYP2C19*3) associated with increased risk of stent thrombosis and frequency of "rapid metabolizer" allele variants (CYP2C19*17), associated with increased risk of clopidogrel-induced bleedings. Five hundred and twelve Russian ethnic group patients from Central Russia (Moscow region), Northern, Central, and Eastern Siberia, presented with ACS, were enrolled in the study. The frequencies of the alleles and genotypes analyzed are shown in Table 1.

Among the 87 cardiac patients from Northern Siberia, frequencies of "PM" allele variants (CYP2C19*2, $C Y P 2 C 19 * 3)$ were $14.9 \%$ and $0.5 \%$, respectively. At the same time, almost one-third $(27.5 \%)$ of the patients carried at least one $C Y P 2 C 19 * 2(* 1 / * 2+* 2 / * 2)$ allele. Frequency of $C Y P 2 C 19 * 17$ allele variant was $33.3 \%$, and almost half of the patients $(49.4 \%)$ carried at least one CYP $2 C 19 * 17$ $(* 1 / * 17+* 17 / * 17)$ allele. The genotype distribution presented in Table 1 showed no deviation from the Hardy-Weinberg equilibrium for "PM" allele variants $\left(* 2: \chi^{2}=0.002, p=0.96\right.$; *3: $\left.\chi^{2}=0.002, p=0.95\right)$, though there was deviation revealed for "extensive metabolizer" ones $\left(* 17: \chi^{2}=6.6, p=0.01\right)$.
In 222 Russian ethnic group patients from Central Siberia, the frequency of the most common "PM" allele variant CYP2C19*2 was $11.05 \%$. No subject with the rarer allele variant $C Y P 2 C 19 * 3$ was detected. Carriers of at least one $C Y P 2 C 19 * 2(* 1 / * 2+* 2 / * 2)$ allele amounted to $22.1 \%$ of the patients studied. Frequency of "extensive metabolizer" allele variant $C Y P 2 C 19 * 17$ was $17.1 \%$ of patients with onethird of them $(31.1 \%)$ carrying at least one CYP 2 C $19 * 17$ $(* 1 / * 17+* 17 / * 17)$ allele. The genotype distribution (Table 1) showed no deviation from Hardy-Weinberg's equilibrium (*2: $\left.\chi^{2}=3.4, p=0.06 ; * 17: \chi^{2}=0.05, p=0.08\right)$.

In 122 Russian ethnic group patients from Eastern Siberia, the frequencies of $C Y P 2 C 19 * 2$ and $C Y P 2 C 19 * 3$ allele variants were $10.6 \%$ and $2.85 \%$, respectively. Nearly quarter of the patients $(20.5 \%)$ carried at least one CYP2C19*2 $(* 1 / * 2+* 2 / * 2)$ allele. The CYP2C19*17 allele frequency was $22.2 \%$, with $40.1 \%$ of the patients carrying at least one CYP2C19*17 $(* 1 / * 17+* 17 / * 17)$ allele. The genotype distribution showed no deviation from Hardy-Weinberg's equilibrium for $C Y P 2 C 19 * 2\left(\chi^{2}=0.13, p=0.71\right)$ and $C Y P 2 C 19 * 17$ $\left(\chi^{2}=0.01, p=0.91\right)$, though there was deviation revealed for $C Y P 2 C 19 * 3\left(\chi^{2}=8.5, p=0.003\right)$.

In $81 \mathrm{ACS}$ patients of Russian ethnic group (Central Russia [Moscow region]), the $C Y P 2 C 19 * 2$ frequency was $8.0 \%$. No subject with $C Y P 2 C 19 * 3$ allele variant was detected in this group. Carriers of at least one CYP2C19*2 allele variant amounted to less than quarter of the patients (16.0\%). The $C Y P 2 C 19 * 17$ allele variant frequency was $15.4 \%$, with almost one-third of the patients $(29.6 \%)$ carrying at least one $C Y P 2 C 19 * 17(* 1 / * 17+* 17 / * 17)$ allele. The allele and genotype distribution showed no deviation from Hardy-Weinberg's equilibrium: $\left(* 2: \chi^{2}=0.61, p=0.43 ; * 17\right.$ : $\chi^{2}=0.42, p=0.42$ ).

Differences in the frequencies of CYP2C19 "poor" and "rapid metabolizer" allele variants between four different groups of patients were measured by Fisher's exact test. Statistically significant difference was found only between Central and Eastern Siberia patients ( $p=0.001$; Table 1).

\section{Discussion}

As cytochrome enzymes (CYP2C9, CYP2D6, CYP2B6, CYP3A4, CYP3A5, and CYP2C19) are responsible for metabolizing over half of all drugs on the market today, it is important for a physician to have valuable information to determine whether a patient's specific genotype may impact their drug response. Particularly, knowing the CYP2C19 phenotype ("extensive metabolizers," "PMs," "IMs," and "UMs") of a patient may help in prescribing optimum dose 
Table I Allele and genotype frequencies and comparison between Russian acute coronary syndrome patients according to geographical region: Moscow region, Northern, Central, and Eastern Siberia (Fisher's exact test)

\begin{tabular}{|c|c|c|c|c|}
\hline \multirow{2}{*}{$\begin{array}{l}\text { Allele and genotype } \mathbf{n}(\%) \\
C Y P 2 C 19 * 2\end{array}$} & \multicolumn{4}{|c|}{ Geographical region of residence } \\
\hline & Northern Siberia & Central Siberia & Eastern Siberia & Moscow region \\
\hline$N$ & 87 & 222 & 122 & 81 \\
\hline$* \mid / * 1$ & $63(72.4)$ & $173(77.9)$ & $97(79.5)$ & $68(84.0)$ \\
\hline$* 1 / * 2$ & $22(25.3)$ & $49(22.1)$ & $24(19.7)$ & $13(16.0)$ \\
\hline$* 2 * / 2$ & $2(2.3)$ & $0(0.0)$ & $\mathrm{I}(0.8)$ & $0(0.0)$ \\
\hline *2 (\%) & 14.9 & 11.5 & 10.6 & 8.0 \\
\hline \multirow[t]{2}{*}{ Central Siberia } & $p=0.307 ; O R=0.92$ & NA & NA & NA \\
\hline & $(95 \% \mathrm{Cl} 0.8-1.07)^{\mathrm{a}}$ & & & \\
\hline \multirow[t]{2}{*}{ Eastern Siberia } & $p=0.24 ; O R=0.91$ & $p=0.78 ; O R=0.98$ & NA & NA \\
\hline & $(95 \% \mathrm{Cl} 0.77-\mathrm{I} .06)$ & $(95 \% \mathrm{Cl} 0.87-1.09)$ & & \\
\hline \multirow[t]{2}{*}{ Moscow region } & $p=0.09 ; O R=0.86$ & $p=0.33 ; O R=0.92$ & $p=0.46 ; O R=0.94$ & NA \\
\hline & $(95 \% \mathrm{Cl} 0.73-1.01)$ & $(95 \% \mathrm{Cl} 0.82-1.04)$ & $(95 \% \mathrm{Cl} 0.83-1.08)$ & \\
\hline $\mathrm{CYP} 2 \mathrm{Cl} 19 * 3$ & - & - & - & - \\
\hline$*|/ *|$ & $86(98.9)$ & $222(100.0)$ & $116(95.1)$ & $81(100.0)$ \\
\hline$* 1 / * 3$ & $I(I . I)$ & $0(0.0)$ & $5(4.1)$ & $0(0.0)$ \\
\hline$* 3 * / 3$ & $0(0.0)$ & $0(0.0)$ & $\mathrm{I}(0.8)$ & $0(0.0)$ \\
\hline *3 (\%) & 0.5 & 0.0 & 2.8 & 0.0 \\
\hline \multirow[t]{2}{*}{ Central Siberia } & $p=0.28 ; O R=0.98$ & NA & NA & NA \\
\hline & $(95 \% \mathrm{Cl} 0.96-1.01)$ & & & \\
\hline \multirow[t]{2}{*}{ Eastern Siberia } & $p=0.24 ; O R=1.01$ & $p=0.00 \mathrm{I} ; \mathrm{OR}=1.05(95 \%$ & NA & NA \\
\hline & $(95 \% \mathrm{Cl} 0.99-1.08)$ & Cl I.01-1.09) & & \\
\hline \multirow[t]{2}{*}{ Moscow region } & $p=1.0 ; O R=0.98$ & Comparison impossible & $p=0.46 ; O R=0.94$ & NA \\
\hline & $(95 \% \mathrm{Cl} 0.96-1.01)$ & & $(95 \% \mathrm{Cl} 0.83-1.08)$ & \\
\hline CYP2CI9*I7 & - & - & - & - \\
\hline$* \mid / * I$ & $44(50.6)$ & $153(68.9)$ & $73(59.8)$ & $57(70.4)$ \\
\hline$* 1 / * 17$ & $28(32.2)$ & $62(27.9)$ & $43(35.2)$ & $23(28.4)$ \\
\hline$* 17 * / * 17$ & $15(17.2)$ & $7(3.2)$ & $6(4.9)$ & $\mathrm{I}(1.2)$ \\
\hline$* 17$ (\%) & 33.3 & 17.1 & 22.2 & 15.4 \\
\hline \multirow[t]{2}{*}{ Central Siberia } & $p=0.07 ; O R=0.82(95 \%$ & NA & NA & NA \\
\hline & $\mathrm{Cl} 0.67-(.02)$ & & & \\
\hline \multirow[t]{2}{*}{ Eastern Siberia } & $p=0.76 ; O R=0.95(95 \%$ & $p=0.09 ;$ OR=I.15 (95\% & NA & NA \\
\hline & $\mathrm{Cl} 0.74-1.21)$ & $\mathrm{Cl} 0.97-1.36)$ & & \\
\hline \multirow[t]{2}{*}{ Moscow region } & $p=0.09 ; O R=0.81 \quad(95 \%$ & $p=0.88 ; O R=0.97(95 \%$ & $p=0.13 ; O R=0.85$ & NA \\
\hline & $\mathrm{Cl} 0.63-1.03)$ & $\mathrm{Cl} 0.82-I .15)$ & $(95 \% \mathrm{Cl} 0.69-1.04)$ & \\
\hline
\end{tabular}

Note: aFisher's exact test not applicable.

Abbreviations: $\mathrm{Cl}$, confidence interval; NA, not applicable; OR, odds ratio.

of drug and in predicting the increased risk of adverse reactions to achieve better therapeutic outcomes. This gives the possibility to predict both individual and population risk of clopidogrel-induced adverse cardiovascular events and treatment inefficiency. The evaluation of the interindividual differences in the prevalence of CYP2C19 gene polymorphisms is very important in the countries such as Russian Federation because of the high multinationality. The results of the pharmacogenetic investigation may be beneficial for developing guidelines for $C Y P 2 C 19$ genotype-directed antiplatelet therapy for each region of the Russian Federation.

According to the results obtained in the present study, from $16 \%$ up to $27.5 \%$ of patients with ACS in different regions of Russia have at least one CYP2C19 "PM" allele variant $(* 1 / * 1+* 1 / * 2)$ affecting clopidogrel metabolism and, therefore, suppressing its antiplatelet activity. Thus, it results in increased risk of thrombotic event, in particular stent thrombosis for ACS patients after percutaneous coronary intervention. ${ }^{11}$ Frequency of CYP $2 C 19 * 2$ allele variant among Russian ACS patients from Northern, Central, and Eastern Siberia was close to that observed among Russian patients from Moscow region, revealed in other previously published studies on stable ACS patients. The study revealed statistically significant differences between the allele frequencies in Eastern and Central Siberia, which can probably be caused by considerable number of Buryats inhabiting Eastern Siberia. Statistically significant differences between CYP2C19*3 allele frequencies observed in Central Siberia and Eastern Siberia can probably be caused by considerable number of Buryats inhabiting Eastern Siberia: Buryats, 
indigenous population of Irkutsk region, account for $2.3 \%$ of total Irkutsk population while they hardly exceed $0.09 \%$ in Kemerovo and Novosibirsk cities. Furthermore, there are less people of Russian ethnic group living in Irkutsk ( $87 \%$ vs. $94.6 \%$ and $92.8 \%$ in Kemerovo and Novosibirsk, respectively). ${ }^{12-14}$

\section{CYP2C19 polymorphism in Russians with ACS and stable CHD from various geographical regions}

The results obtained from this study on ACS patients were compared with those of the previously published data on frequencies of $C Y P 2 C 19$ allele variants $(C Y P 2 C 19 * 2$, $C Y P 2 C 19 * 3, C Y P 2 C 19 * 17)$ in Russian ethnic group patients with CHD. ${ }^{15-17}$ CYP 2 C19*2 prevalence was observed to be significantly higher in Russian patients with stable coronary heart disease (CHD) from Moscow region, ${ }^{15}$ when compared with that in the Central Russian (Moscow region) patients enrolled in the current study $(15.05 \%$ vs. $8 \% ; p=0.03$; odds ratio $[\mathrm{OR}]=1.18[95 \%$ confidence interval $\{\mathrm{CI}\} 1.01-1.38])$. Similarly, CYP2C19*3 prevalence was higher in Russian patients in the study conducted by Mirzaev et al as compared to that among the patients from Central Siberia enrolled in the current study $(p=0.002$; $\mathrm{OR}=1.05$ [95\% CI 1.006-1.01]). Finally, the prevalence of $C Y P 2 C 19 * 17$ allele variant was higher among Russian patients from Northern Siberia, when compared with that observed among Russian CHD patients from Moscow region studied by Komarov et al ( $33.3 \%$ vs. $20.6 \% ; p=0.01$; $\mathrm{OR}=0.77$ [95\% CI $0.62-0.96]) .{ }^{16}$ There were no statistically significant differences between $C Y P 2 C 19 * 2$ and CYP2C19*3 allele variants frequencies in the patients of the current study when compared with those in the patients with chronic CHD from Tomsk (Western Siberia) ( $p>0.05$ ). ${ }^{3}$ Among Ural ACS patients (Chelyabinsk city), treated with coronary stent implantation, frequencies of $C Y P 2 C 19 * 2$ and CYP2C19*3 allele variants were $12.5 \%$ and $0.0 \%$, respectively, and no statistically significant differences compared from the data of this study $(p>0.05) .{ }^{18}$

\section{Allele frequencies of $\mathrm{CYP} 2 \mathrm{Cl} 9$ from different ethnic populations in the Russian Federation and other countries}

The frequency of CYP $2 C 19 * 2, C Y P 2 C 19 * 3$, and CYP2C19*17 polymorphisms differs markedly in human populations (Table 2). According to the published data, the highest frequency of $C Y P 2 C 19 * 2$ allele occurs in healthy
Table 2 CYP2C19*2, CYP2C19*3, and CYP2C19*17 frequencies in human populations

\begin{tabular}{lllll}
\hline CYP2C19 allele (\%) & \multicolumn{4}{l}{ Human populations } \\
\cline { 2 - 5 } & European $^{28}$ & Asian $^{29}$ & Hispanic $^{30}$ & African $^{31}$ \\
\hline CYP2C19*2 & 15.1 & 34.5 & 12.6 & 12.6 \\
CYP2C19*3 & 0.0 & 9.0 & 0.0 & 1.0 \\
CYP2C19*17 & 25.7 & 0.5 & 14.0 & 17.2 \\
\hline
\end{tabular}

volunteers among Pacific Islands population accounting for $63.3 \%,{ }^{19}$ while the rarest frequency is observed among Dargins $(6 \%) .{ }^{20}$ The highest frequency of $C Y P 2 C 19 * 3$ allele variant was observed among the Pacific Islands population $-14.4 \%{ }^{19}$ CYP $2 C 19 * 17$ allele variant prevalence in ethnic groups: $25.7 \%, 22.0 \%$, and $20.0 \%$ among Germans, Norwegians, and Swedes, respectively, ${ }^{21}$ but in Chinese and Tai $-2.6 \%$ and $4.3 \%{ }^{22,23}$ According to the previously published studies, the highest frequency of CYP 2 C19*17 allele variant was reported to occur among Lithuanian ACS patients (31\%) and Russian patients diagnosed with peptic ulcer $(27.4 \%) .^{24,25}$ Our results indicate that $C Y P 2 C 19 * 17$ allele variant frequency was $33.3 \%$ among Russian ethnic group patients from Northern Siberia, thus exceeding the frequency revealed in the previously published studies.

The ethnic distribution of CYP2C19 in Russia was investigated among Tatars, Carachays, Circassians, Ingushes, Chechens, Kalmyks, Avars, Laks, Dargins, Bashkirs, Yakuts, Buryats, Altayans, and Tuvinians in previous studies (Table 3).

Table 3 Frequency distribution of CYP2C19*2, CYP2C19*3, and CYP2C19* I 7 allele variants among ethnic groups in Russia

\begin{tabular}{|c|c|c|c|c|}
\hline \multirow[t]{2}{*}{ Ethnic groups } & \multirow[t]{2}{*}{ Type of subjects } & \multicolumn{3}{|c|}{ Allele frequencies } \\
\hline & & $* 2$ & $* 3$ & $* 17$ \\
\hline Russians $^{15}$ & $\mathrm{CHD}$ & 0.12 & 0.0 & 0.22 \\
\hline Russians $^{16}$ & $\mathrm{CHD}$ & 0.15 & 0.0 & 0.14 \\
\hline Tatars $^{32}$ & Healthy & 0.12 & 0.21 & n.d. \\
\hline Kalmyks 33 & Healthy & 0.15 & n.d. & n.d. \\
\hline Tuvinians $^{34}$ & Healthy & 0.15 & 0.02 & n.d. \\
\hline Buryats ${ }^{34}$ & Healthy & 0.21 & 0.07 & n.d. \\
\hline Yakuts $^{34}$ & Healthy & 0.23 & 0.05 & n.d. \\
\hline Altayans ${ }^{34}$ & Healthy & 0.15 & 0.04 & n.d. \\
\hline Chechens $^{33}$ & Healthy & 0.13 & n.d. & n.d. \\
\hline Carachays $^{35}$ & Healthy & 0.14 & n.d. & n.d. \\
\hline Circassians $^{35}$ & Healthy & 0.19 & n.d. & n.d. \\
\hline Ingushes ${ }^{33}$ & Healthy & 0.08 & n.d. & n.d. \\
\hline Laks $^{20}$ & Healthy & 0.14 & n.d. & n.d. \\
\hline Dargins ${ }^{20}$ & Healthy & 0.05 & n.d. & n.d. \\
\hline Avars $^{20}$ & Healthy & 0.13 & n.d. & n.d. \\
\hline
\end{tabular}

Abbreviations: CHD, coronary heart disease; n.d., no data. 
The results of the study demonstrated that $38.0 \%$ of Kalmyks, $23.0 \%$ of Russians, $20.0 \%$ of Tatars, $18.0 \%$ of Chechens, and $12.0 \%$ of Ingushes carried at least one CYP $2 C 19 * 2$ allele variant. Relatively high frequencies of CYP2C19*2 allele variants and genotypes among Kalmyk population are determined by their Mongoloid origin. The prevalence of $C Y P 2 C 19 * 2$ polymorphic marker was not limited to Ingush and Chechen populations but proved to be identified among other five Caucasus populations, such as Carachays, Circassians, Laks, Dargins, and Avars (Table 3). Frequencies of CYP2C19*2 "PM" allele variant among Carachay and Circassian populations were 18.8\% and $14.0 \%$, respectively. According to the results obtained, $31.2 \%$ of Circassians and $26.4 \%$ of Carachays carried at least one $C Y P 2 C 19 * 2$ allele variant, while frequency of this allele variant among Avar, Lak, and Dargin populations accounted to $12.7 \%, 14.5 \%$, and $5.0 \%$, respectively (Table 3). Frequency of CYP2C19*2 allele variant among Dargin population was identified as relatively low when compared with other ethnic groups. Therefore, further research on bigger samples is required. $C Y P 2 C 19$ allele frequency observed in this region was similar to average meanings for most European populations (Table 2). Additionally, CYP 2 C19*2, *3 polymorphic marker prevalence has been identified among Bashkirs ${ }^{26}$, Yakuts, Buryats, Altayans, and Tuvinians with the results being similar to those on Asian population (Table 2). In the study on 130 Russian subjects from Tomsk city, Freidin et al investigated 67 women and

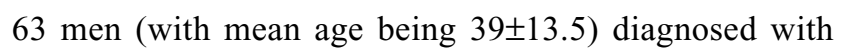
allergic disease. The results of the research demonstrated that the frequency of $C Y P 2 C 19 * 2$ allele variant was $17.4 \%$, and $C Y P 2 C 19 * 1 / * 1, C Y P 2 C 19 * 1 / * 2$, and $C Y P 2 C 19 * 2 / * 2$ genotypes distribution accounted for $66.9 \%$ (81), 31.4\% (38), and $1.7 \%$ (2), respectively. ${ }^{27} \mathrm{CYP} 2 \mathrm{C} 19 * 17$ allele variant has been identified in the Central Russia (Moscow city) among patients with peptic ulcer and its frequency accounted for $27.4 \%,{ }^{25}$ while the result obtained in the present study accounted for $15.4 \%$.

\section{Conclusion}

The variability in the distribution of $C Y P 2 C 19 * 2$, *3, and $* 17$ among populations reflects a population-specific pattern, which stresses the need to genotyping these alleles for the patients. The results of the present study will facilitate physicians prescribing clopidogrel by providing an approximate percentage of "poor" and UMs in Russians and may be helpful for development of guidelines for CYP2C19 genotype-directed antiplatelet therapy in Russian patients with ACS.

\section{Acknowledgments}

The authors are grateful to Konova OD (Russian Medical Academy of Postgraduate Education, Ministry of Health of the Russian Federation, Moscow, Russia), Gilyarov MY (Sechenov I.M. First Moscow State Medical University, Ministry of Health of the Russian Federation, Moscow, Russia), Andreev DA (Sechenov I.M. First Moscow State Medical University, Ministry of Health of the Russian Federation, Moscow, Russia), Kochergin NA (Federal State-Financed Research Institution "Research Institute for Complex Issues of Cardiovascular Diseases," Siberian Branch of the Russian Academy of Sciences, Kemerovo, Russia), Gorohova AV (Federal State-Financed Research Institution "Irkutsk Research Center," Siberian Branch of the Russian Academy of Sciences, Irkutsk, Russia), Batueva KY (State-Financed Institution of Higher Education "Surgut State University," Surgut, Russia) for their suggestions and editing support (conceptual and editorial supports) and Grishina EA, Ryzhikova KA, Sozaeva ZhA, at the research center of Russian Medical Academy of Postgraduate Education, Ministry of Health of the Russian Federation, Moscow, Russia, for skilled laboratory work (assistance in the genotyping).

\section{Disclosure}

Part of the research on the frequencies of CYP 2 C19*2, *3, and $* 17$ gene polymorphisms observed in the patients of Moscow region has been supported by Russian Science Foundation - project 16-15-00227 "Fundamental research and exploratory research conducted in the top priority areas".

Part of the research on the frequencies of CYP 2 C19*2, $* 3$, and $* 17$ gene polymorphisms observed in the patients of Siberian region has been conducted under the government contract "Development of a portable system aimed at multiparameter control of human coagulation system functional properties"; agreement No 14.697.21.0066; project unique identifier is RFMEFI60714X0066. The authors report no other conflicts of interest in this work.

\section{References}

1. Information bulletin WHO: Top 10 causes of death worldwide. Available from: http://www.who.int/mediacentre/factsheets/fs310/ru/. Updated January 2017. Accessed February 03, 2013

2. Mancia G, Fagard R, Narkiewicz K, et al. Рекомендации по лечению артериальной гипертонии ESH/ESC 2013 [Guidelines on hypertension treatment ESH/ESC 2013]. Ros Kardiol Zhurnal [Russian J Cardiol]. 2014;1:7-94. Russian

3. Knauer NY, Lifshits GI. Молекулярно-генетический подход к оптимизации современной антиагрегантной терапии [Molecular genetic approach to contemporary antiplatelet therapy optimization]. Bull East-Siberian Sci Center SB RAMS. 2012;2-1(84):143-152. Russian

4. Mega JL, Simon T, Collet JP, et al. Reduced-function CYP2C19 genotype and risk of adverse clinical outcomes among patients treated with clopidogrel predominantly for PCI: a meta-analysis. JAMA. 2010;304(1): 1821-1830. 
5. Knauer NY, Lifshits GI, Voronina EN, et al. Информативность генетических маркеров для оптимизации персонализированной терапии клопидогрелом [Informativeness of genetic factors for optimization of personalized therapy with clopidogrel]. Kardiologiia. 2013;53(8):72-75. Russian.

6. Ahmad T, Voora D, Becker RC. The pharmacogenetics of antiplatelet agents: towards personalized therapy? Nat Rev Cardiol. 2011;8(10): 560-571.

7. Harmsze AM, van Werkum JW, ten Berg JM, et al. CYP2C19*2 and CYP2C $9 * 3$ alleles are associated with stent thrombosis: a case-control study. Eur Heart J. 2010;31(24):3046.

8. Sibbing D, Stegherr J, Latz W, et al. Cytochrome P450 2C19 loss-offunction polymorphism and stent thrombosis following percutaneous coronary intervention. Eur Heart J. 2009;30(8):916-922.

9. Sipeky C, Weber A, Szabo M, et al. High prevalence of CYP2C19*2 allele in Roma samples: study on Roma and Hungarian population samples with review of the literature. Mol Biol Rep. 2013;40(8):=4727-4735.

10. Lifshits GI, Danilkina ST, Guskova EV, et al. Ассоциация генов, кодирующих белки гемостаза, с параметрами периферического гемостаза и предрасположенностью к атеротромбозам у пациентов с сердечно-сосудистыми заболеваниями [Hemostasis protein-coding genes, peripheral hemostasis parameters, and atherothrombosis predisposition in patients with cardiovascular disease]. Cardiovasc Therapy Prevent (Russian Federation). 2011;4:90-96. Russian.

11. Kupstyte N, Zaliunas R, Tatarunas V, et al. Effect of clinical factors and gene polymorphisms of CYP2C19*2, * 17 and CYP4F $2 * 3$ on early stent thrombosis. Pharmacogenomics. 2015;16(3):181-189.

12. Mega JL, Close SL, Wiviott SD, et al. Cytochrome P-450 polymorphisms and response to clopidogrel. N Engl J Med. 2009;360(4):354-362.

13. Population of Irkutsk city according to Russian census 2010. Irkutskstat 2012. Irkutsk.

14. Ethnic composition of municipal divisions population of Novosibirsk region. Local Agency of the Federal State Statistics Service of Novosibirsk Region. 2013. Novosibirsk.

15. Mirzaev KB, Sychev DA, Karkischenko VN, et al. Частота полиморфных маркеров СҮР2С19*2, СҮР2C19*3, СҮР2С19*17 среди русской популяции и сравнение распространенности CYP2C19*2 у пациентов с ишемической болезнью сердца, получающих терапию клопидогрелем, и здоровых добровольцев [CYP2C19*2, CYP2C19*3, CYP2C19*17 allele and genotype frequencies in clopidogrel-treated patients with coronary heart disease from the Russian population]. Biomedicine. 2013;2:117-128. Russian.

16. Komarov AL, Shakhmatova OO, Ilyushenko TA, et al. Оценка риска сердечно-сосудистых осложнений у больных стабильной ИБС, получающих клопидогрел: функция тромбоцитов или генетические исследования? [Assessment of cardiovascular complications risk in patients with stable ACS treated with klopidogrel: platelet function or genetic testing?] Doktor:Ru. 2012;6:11-19. Russian.

17. Muslimova EF. Molecular Genetic Factors of Complications Development after Coronary Stent Implantation in Patients with Stable ACS [PhD dissertation]. 14.03.03 - pathophysiology. 14.01.05-cardiology. Siberian State Medical University. 2016;Tomsk: 236. Available from: http://www.ssmu.ru/upload/filesarchive/files/dissertacija_Muslimova_ file_1_1402.pdf. Accessed February 03, 2013.

18. Barysheva VO, Ketova GG. Pharmacogenetic testing in population of South Ural. Int J Risk Saf Med. 2015;27:25-26.

19. Kaneko A, Lum JK, Yaviong J, et al. High and variable frequencies of CYP2C19 mutations: medical consequences of poor drug metabolism in Vanuatu and other Pacific islands. Pharmacogenetics. 1999;9(5):581-590.

20. Mirzaev KB. Genotyping and Phenotyping of Cytochrome P-450 Isoenzymes for the Purpose of Predicting Clopidogrel Antiplatelet Activity in ACS Patients: Clinical and Ethnic Aspects. [PhD dissertation]. 14.03.06 - pharmacology, clinical pharmacology. I.M. Sechenov Firs Moscow State Medical University. 2016; Moscow: 143p. Available from: http://www.mma.ru/upload/medialibrary/c53/dissretatsiya_mirzaev_ kb_13.03.2016.pdf. Accessed February 03, 2013.
21. Geisler T, Schaeffeler E, Dippon J, et al. CYP2C19 and nongenetic factors predict poor responsiveness to clopidogrel loading dose after coronary stent implantation. Pharmacogenomics. 2008;9(9):1251-1259.

22. Pedersen RS, Brasch-Andersen C, Sim SC, et al. Linkage disequilibrium between the CYP2C19*17 allele and wildtype CYP2C8 and CYP2C9 alleles: identification of CYP2C haplotypes in healthy Nordic populations. Eur J Clin Pharmacol. 2010;66(12):1199-1205.

23. Feng G, Liang Y, Ying B, et al. Clopidogrel metabolism related gene polymorphisms in Chinese patients with acute coronary syndrome. Zhonghua Xin Xue Guan Bing Za Zhi. 2012;40(11):908-913.

24. Chonlaphat S, Ramaimon T, Montri C, et al. CYP2C19 polymorphisms in the Thai population and the clinical response to clopidogrel in patients with atherothrombotic-risk factors. Pharmgenomicsd Pers. 2013;6: 85-91.

25. Denisenko NP, Sychev DA, Sizova Zh.M, et al. Высокая распространенность быстрых метаболизаторов по СҮР2C19 среди российских пациентов с язвенной болезнью [High frequency of CYP2C19 ultrarapid metabolizers in Russian patients with peptic ulcer]. Clin Exp Gastroenterol. 2015;6:11-15. Russian.

26. Nizhevich AA, Yunusbaev BB, Tuygunov MM, et al. Изучение полиморфизма генов, ответственных за метаболизм ингибиторов протонной помпы у детей с H. PYLORI инфекцией: есть ли связь с эффективностью эрадикационной терапии? [Studying the polymorphisms of genes responsible for the metabolism of proton pump inhibitors in children with $\mathrm{H}$. Pylori infection: is there a connection with the effectiveness of eradication therapy?] Clin Exp. 2009;3:101-104. Russian.

27. Freidin MB, Bragina E.Yu, Petrouskiy FI, et al. Анализ связи полиморфизма генов GSTT1, GSTM1, CYP2C19, CYP2E1c атопией у жителей г. Томска. [Association of the GSTT1, GSTM1, CYP2C19, CYP2E1 genes polymorphism with atopy]. Med Immunol. 2003;5(1-2):107-112. Russian.

28. Collet JP, Hulot JS, Pena A, et al. Cytochrome P450 2C19 polymorphism in young patients treated with clopidogrel after myocardial infarction: a cohort study. Lancet. 2009;373:309-317.

29. Al-Jenoobi FI, Alkharfy KM, Alghamdi AM, et al. CYP2C19 genetic polymorphism in Saudi Arabians. Basic Clin Pharmacol Toxicol. 2013;112(1):50-54.

30. Myrand SP, Sekiguchi K, Man MZ, et al. Pharmacokinetics/genotype associations for major cytochrome P450 enzymes in native and first- and third-generation Japanese populations: comparison with Korean, Chinese, and Caucasian populations. Clin Pharmacol Ther. 2008;84(3):347-361.

31. Miura J, Obua C, Abbo C, et al. Cytochrome P450 2C19 genetic polymorphisms in Ugandans. Eur J Clin Pharmacol. 2009;65(3):319-320.

32. Khalikova AR, Arkhipova AA, Ahmetov II, et al. Изучение полиморфизма гена цитохрома Р-450 CYР2С19 в популяции татар, проживающих на территории Республики Татарстан [The study of cytochrome P-450 CYP2C19 gene polymorphisms in population of Tatars living in Republic of Tatarstan]. Praktichesk Med. 2012;3(58):5355. Russian

33. Kantemirova BI, Timofeeva NV, Sychev DA, et al. Сравнительное изучение полиморфизма гена СYР2C19 у детей, проживающих в Астраханском регионе [A comparative study of CYP2C19 gene polymorphism in children living in the Astrakhanian region]. Astrahansk Med Zhurn [Astrakhan Med J]. 2011;3:153-155. Russian.

34. Makeeva O, Stepanov V, Puzyrev V, et al. Global pharmacogenetics: genetic substructure of Eurasian populations and its effect on variants of drug-metabolizing enzymes. Pharmacogenomics. 2008;9(7): $847-868$.

35. Romodanovsky DP, Khapaev BA, Ignatiev IV, et al. Частоты «медленных» аллельных вариантов генов, кодирующих изоферменты цитохрома P450 CYP2D6, CYP2C19, CYP2C9 у карачаевцев и черкесов [Frequencies of the "slow" allele variants of the genes coding isoenzymes of cytochrome P450 CYP2D6, CYP2C19, CYP2C9 in Karachaevs and Circassians]. Biomedicine. 2010;2:33-37. Russian 


\section{Publish your work in this journal}

Pharmacogenomics and Personalized Medicine is an international, peerreviewed, open access journal characterizing the influence of genotype on pharmacology leading to the development of personalized treatment programs and individualized drug selection for improved safety, efficacy and sustainability. This journal is indexed on the American Chemical
Society's Chemical Abstracts Service (CAS). The manuscript management system is completely online and includes a very quick and fair peer-review system, which is all easy to use. Visit http://www.dovepress. com/testimonials.php to read real quotes from published authors.

Submit your manuscript here: https://www.dovepress.com/pharmacogenomics-and-personalized-medicine-journal 